\title{
ANALISIS PERBANDINGAN METODE AHP DAN TOPSIS PADA SISTEM PENDUKUNG KEPUTUSAN PEMILIHAN MENU MAKANAN UNTUK ANAK PASCA OPERASI HISPHRUNG BERBASIS WEB
}

\author{
Vingki Indrayani Maulidina, Mira Orisa, FX. Ariwibisono \\ Program Studi Teknik Informatika S1, Fakultas Teknologi Industri \\ Institut Teknologi Nasional Malang, Jalan Raya Karanglo km 2 Malang, Indonesia \\ vingkiindra9@gmail.com
}

\begin{abstract}
ABSTRAK
Dalam kehidupan sehari-hari makanan merupakan kebutuhan yang sangat penting. Pada zaman saat ini banyak sekali berbagai jenis menu makanan beredar. Dengan banyaknya jenis makanan kita harus pandai memilih makanan sesuai dengan kebutuhan tubuh kita. Pola makan yang tidak benar dapat mendatangkan penyakit bagi tubuh kita. Tujuan yang ingin dicapai dalam penelitian ini adalah membuat aplikasi yang bertujuan untuk memudahkan orang tua anak penderita penyakit Hisphrung untuk memilih menu makanan yang tepat dengan memperhatikan kandungan makanan yang baik dikonsumsi ataupun tidak.

Adapun luaran yang diharapkan dalam penelitian ini adalah menghasilkan suatu sistem pendukung keputusan yang di gunakan untuk pemilihan menu makanan bagi anak pasca operasi Hisphrung dan memberikan inovasi baru tentang sistem pendukung keputusan untuk pemilihan menu makanan bagi anak pasca operasi Hisphrung. Metode yang dipakai dalam pencapaian tujuan tersebut adalah metode Analytical Hierarchy Program (AHP) dan Technique for Order by Similarity to Ideal Solution (TOPSIS). Dari hasil pengujian yang di lakukan terhadap tiap-tiap fungsional sistem dengan akses sebagai user berjalan $100 \%$. Berdasarkan hasil pengujian kuisioner di dapat hasil presentase $70 \%$ yang menyatakan baik, sehingga dapat di simpulkan bahwa metode AHP dan TOPSIS dapat di terapkan untuk menentukan rekomendasi menu makanan.
\end{abstract}

Kata kunci : Analytical Hierarchy Program (AHP), Technique for Order by Similarity to Ideal Solution (TOPSIS), Hisphrung

\section{PENDAHULUAN}

\subsection{Latar Belakang}

Di era global saat ini banyak sekali jenis makanan cepat saji yang ada di sekitar kita. Dengan banyaknya jenis makanan yang ada kita harus pandai dalam memilih makanan dan mengatur pola makan kita sesuai dengan kebutuhan tubuh kita. Pola makan yang tidak benar dapat mendatangkan penyakit bagi tubuh kita. Penyakit Hisphrung adalah gangguan pada usus besar yang menyebabkan feses atau tinja terjebak di dalam usus. Penyakit Hisphrung terjadi karena kelainan saraf yang mengontrol pergerakan usus besar. Hal ini menyebabkan usus besar tidak dapat mendorong feses keluar, sehingga menumpuk di usus besar dan bayi tidak bisa buang air besar.

Pemahaman mengenai penyakit Hisphrung di Indonesia masih kurang di perhatikan sehingga pasien sering terlambat mengetahui tentang penyakit Hisphrung ini. Ketidakpahaman penderita mengenai makanan apa saja yang baik atau tidak bagi penderita penyakit Hisphrung pasca operasi merupakan suatu kendala dalam penyembuhan. Maka dari itu, memilih menu makanan penderita penyakit Hisphrung yang tepat dengan memperhatikan kandungan-kandungan makanan yang baik dikonsumsi ataupun tidak.

Berdasarkan permasalahan yang sudah di paparkan sebelumnya, maka penyusun akan merancang Sistem Pendukung Keputusan Pemilihan Menu Makanan Untuk Anak Pasca Operasi Hisphrung Menggunakan Metode AHP Dan TOPSIS Berbasis Web, dengan tujuan untuk membantu orang tua para penderita penyakit Hisphrung pasca operasi dalam memilih menu makanan yang tepat dan baik dengan memperhatikan kandungan-kandungan makanan yang baik dikonsumsi ataupun tidak.

\subsection{Rumusan Masalah}

Berdasarkan latar belakang permasalahan, maka masalah-masalah yang ada dapat di rumuskan sebagai berikut :

1. Bagaimana cara membangun Sistem Pendukung Keputusan Pemilihan Menu Makanan Untuk Anak Pasca Operasi Hisphrung Menggunakan Metode AHP Dan TOPSIS Berbasis Web.

2. Bagaimana mengimplementasikan metode AHP dan TOPSIS untuk pemilihan menu makanan bagi anak pasca operasi Hisphrung.

\subsection{Batasan Masalah}

Adapun batasan masalah dalam pembuatan aplikasi sebagai berikut :

1. Sistem pendukung keputusan yang dibuat berbasis web.

2. Usia yang di gunakan pada penelitian ini yaitu usia 1 tahun sampai dengan 5 tahun. 
3. Makanan yang tidak boleh di konsumsi yaitu makanan yang mengandung kacang-kacangan.

4. Metode yang di gunakan pada Sistem Pendukung Keputusan Pemilihan Menu Makanan Untuk Anak Pasca Operasi Hisphrung yaitu metode AHP Dan TOPSIS.

5. Software yang di gunakan untuk pengembangan Sistem Pendukung Keputusan Pemilihan Menu Makanan Untuk Anak Pasca Operasi Hisphrung yaitu MySQL (untuk mengelola database), Sublime Text (untuk text editor), PHP dan HTML (untuk bahasa pemrogramannya).

6. Target pengguna dari pengembangan Sistem Pendukung Keputusan Pemilihan Menu Makanan Untuk Anak Pasca Operasi Hisphrung yaitu para orang tua penderita penyakit Hisphrung atau pun manajemen rumah sakit.

7. Platform yang digunakan untuk mengembangkan Sistem Pendukung Keputusan Pemilihan Menu Makanan Untuk Anak Pasca Operasi Hisphrung yaitu berbasis web.

\subsection{Tujuan}

Adapun tujuan dari pembuatan Sistem Pendukung Keputusan Pemilihan Menu Makanan Untuk Anak Pasca Operasi Hisphrung ini adalah sebagai berikut :

1. Membuat sebuah Sistem Pendukung Keputusan Pemilihan Menu Makanan Untuk Anak Pasca Operasi Hisphrung Menggunakan Metode AHP Dan TOPSIS Berbasis Web.

2. Mengimplementasikan metode AHP dan TOPSIS untuk pemilihan menu makanan bagi anak pasca operasi Hisphrung.

3. Melakukan perbandingan metode AHP dan TOPSIS untuk pemilihan menu makanan bagi anak pasca operasi Hisphrung.

\section{TINJAUAN PUSTAKA}

\subsection{Penelitian Terdahulu}

Menurut penelitian Rizky Ria Kumaladewi dan

Sri Kusumadewi tentang penelitiannya yang berjudul "Sistem Pendukung Keputusan Pemilihan Menu Makanan Bagi Anak". Penelitian yang mereka buat menggunakan metode CBR (Case Based Reasoning). Sistem yang mereka buat bertujuan agar orang tua tidak mengalami kesulitan dalam memilih menu makanan berdasarkan bahan makanan yang dimiliki yang sesuai dengan kebutuhan energi anak. Pada sistem ini pertama yang di lakukan untuk mendapatkan saran menu makanan, user harus melakukan pendataan anak dengan mengisikan data seperti nama, jenis kelamin, umur, dan berat badan. Setelah pengisian data anak, kemudian di proses untuk melihat saran menu makanan yang di pilih. [1]

Menurut penelitian Marsono, dkk (2015) tentang penelitiannya yang berjudul "Sistem Pendukung Keputusan Pemilihan Menu Makanan Pada Penderita Obesitas Dengan Menggunakan
Metode Topsis". Penelitian tersebut di lakukan untuk menentukan menu makanan yang tepat untuk penderita obesitas. Dalam penentuan menu makanan, kriteria yang di gunakan yaitu karbohidrat, protein, lemak, kalori, dan kolestrol. [2] Selanjutnya Yustria Handika Siregar dan Sri Rahayu (2018) telah melakukan penelitian yang berjudul "Sistem Pendukung Keputusan Pemilihan Menu Makanan bagi Anak dengan Metode Analitycal Hierarchy Process (AHP)". Penelitian tersebut di lakukan dengan tujuan memudahkan orang tua memilih menu makanan untuk bekal sekolah sang anak. Kriteria yang di gunakan untuk penentuan menu makanan mereka menggunakan 4 kriteria yaitu karbohidrat, kandungan garam, kandungan serat, tidak mengandung pewarna dan pengawet. [3]

Menurut penelitian Efi Laila Latifah (2012) tentang penelitiannya yang berjudul "Sistem Pendukung Keputusan Untuk Menentukan Menu Makanan Sehat Dengan Metode Elimination Et Choix Traduisant La Realité (ELECTRE)". Penelitian di buat untuk membantu masyarakat dalam penentuan menu makanan dengan menggunakan metode Elimination Et Choix Traduisant La Realité (ELECTRE). Dalam penentuan menu makanan kriteria yang di gunakan ada 5 yaitu nilai jumlah kalori, berat, karbohidrat, protein, dan lemak. Untuk alternatifnya menggunakan menu makanan beserta kandungan gizinya yang sudah di pertimbangkan oleh ahli gizi. [4]

Menurut penelitian Anshori (2016) tentang penelitiannya yang berjudul "Sistem Pendukung Keputusan Pemilihan Bahan Makanan Bergizi Untuk Manula Menggunakan Metode Simple Additive Weighting". Penelitian ini di lakukan bertujuan untuk mempermudah pengguna dalam pemilihan menu makanan yang bergizi bagi manula. Kriteria yang di gunakan dalam penelitian ini yaitu jenis kelamin, umur, penyakit dan alergi. Dari penelitian ini menghasilkan sebuah aplikasi yang dapat membantu dalam menentukan menu makanan yang baik untuk manula. [5]

\subsection{Penyakit Hisphrung}

Penyakit Hisphrung adalah suatu kondisi tidak adanya segmen ganglion intrinsik parasimpatis pada submukosa dan myenteric plexuses yang secara anatomi terletak pada bagian anus dan membentang secara proksimal (Amiel, et al., 2001). [6] Penyakit Hisphrung terjadi karena adanya penumpukan feses atau tinja di usus besar, sehingga usus besar tidak dapat mendorong feses keluar.

\subsection{Metode TOPSIS (Technique for Order by Similarity to Ideal Solution)}

Metode TOPSIS adalah salah satu metode yang digunakan untuk menyelesaikan masalah Multi Attribute Decision Making (MADM). Metode 
TOPSIS merupakan suatu metode yang digunakan untuk pengambilan keputusan yang optimal dalam menyelesaikan masalah secara praktis (Fatkhurrochman, 2018) [7]. Tahapan metode TOPSIS sebagai berikut :

1. Membuat matriks perbandingan berpasangan yang ternormalisasi $(\mathrm{R})$

$$
r_{i j}=\frac{x_{i j}}{\sqrt{\sum_{i=1}^{m} x_{i j}^{2}}} \quad \text { Persamaan } 1
$$

dengan $\mathrm{i}=1,2, \ldots, \mathrm{m}$; nilai $\mathrm{m}$ menunjukkan jumlah alternatif yang dievaluasi, dan nilai $\mathrm{X}_{\mathrm{ij}}$ menunjukkan nilai rating kecocokan alternatif ke-i terhadap kriteria ke-j.

2. Membuat matriks keputusan yang ternormalisasi terbobot (Y)

Nilai dari masing-masing data ternormalisasi (R) kemudian dikalikan dengan bobot (W) untuk mendapatkan matriks keputusan ternormalisasi terbobot (Y).

$$
y_{i j}=w_{i} \cdot r_{i j} \quad \text { Persamaan } 2
$$

3. Matriks Solusi Ideal Positif $\left(\mathrm{A}^{+}\right)$dan Negatif ( $\mathrm{A}^{-}$ )

- Solusi Ideal Positif $\left(\mathrm{A}^{+}\right)$

Persamaan yang digunakan untuk menentukan solusi ideal positif adalah :

$$
A^{+}=\left(y_{1}^{+}, y_{2}^{+}, y_{3}^{+}, \ldots, y_{n}^{+} \quad \text { Persamaan } 3\right.
$$

- Solusi Ideal Negatif $\left(\mathrm{A}^{-}\right)$

Persamaan yang digunakan untuk menentukan solusi ideal negatif adalah :

$$
A^{-}=\left(y_{1}^{-}, y_{2}^{-}, y_{3}^{-}, \ldots, y_{n}^{-} \quad \text { Persamaan } 4\right.
$$

4. Jarak Solusi Ideal Positif dan Negatif (D)

- Jarak Solusi Ideal Positif

$$
D_{i}^{+}=\sqrt{\sum_{j=1}^{n}\left(y_{i}^{+}-y_{i j}\right)^{2}} \quad \text { Persamaan } 5
$$

- Jarak Solusi Ideal Negatif

$$
D_{i}^{-}=\sqrt{\sum_{j=1}^{n}\left(y_{i j}-y_{i}^{-}\right)^{2}} \quad \text { Persamaan } 6
$$

\section{Keterangan}

- $\boldsymbol{y}_{j}^{+}=$solusi ideal positif untuk atribut ke-j

- $y_{j}^{-}=$solusi ideal negatif untuk atribut ke-j

- $y_{i j}=$ elemen dari matriks keputusan yang ternormalisai terbobot $\mathrm{Y}$

5. Nilai Preferensi (V)

$$
V_{i}=\frac{D_{i}^{-}}{D_{i}^{-}+D_{i}^{+}}
$$

Persamaan 7

Nilai $V_{i}$ yang lebih besar menunjukkan bahwa alternatif $\mathrm{A}_{\mathrm{i}}$ lebih dipilih

\subsection{Metode AHP}

Metode AHP merupakan suatu metode yang digunakan untuk menemukan skala rasio dari matrik perbandingan berpasangan. Metode AHP menguraikan suatu masalah dengan membuat suatu hirarki. Dengan adanya hirarki ini, masalah yang kompleks akan tampak lebih terstruktur dan sistematis. [8]

Langkah-langkah penyelesaian metode AHP yaitu sebagai berikut (Saaty, 2008): [9]
A. Mendefinisikan masalah dan menentukan solusi yang diinginkan, lalu menyusun hierarki dari permasalahan yang dihadapi.

B. Menentukan Prioritas Elemen
a. Langkah pertama dalam menentukan prioritas elemen adalah membuat perbandingan pasangan, yaitu membandingkan elemen secara berpasangan sesuai kriteria yang diberikan.

C. Sintesis

Pertimbangan-pertimbangan terhadap perbandingan berpasangan disintesis untuk memperoleh keseluruhan prioritas. Hal-hal yang dilakukan dalam langkah ini adalah :

a. Menjumlahkan nilai-nilai dari setiap kolom pada matriks $\mathrm{K}$.

b. Membagi setiap nilai dari kolom dengan total kolom yang bersangkutan untuk memperoleh normalisasi matriks.

c. Menjumlahkan nilai-nilai dari setiap baris dan membaginya dengan jumlah elemen untuk mendapatkan nilai bobot prioritas.

D. Mengukur Konsistensi

Dalam pembuatan keputusan, penting untuk mengetahui seberapa baik konsistensi yang ada karena kita tidak menginginkan keputusan berdasarkan pertimbangan dengan konsistensi yang rendah. Hal-hal yang dilakukan dalam langkah ini adalah sebagai berikut :

a. Setiap nilai pada kolom pertama dikalikan dengan bobot prioritas elemen pertama, kemudian setiap nilai pada kolom kedua dikalikan dengan bobot prioritas elemen kedua dan seterusnya.

b. Jumlahkan setiap baris ( $\sum$ baris).

c. Hasil dari penjumlahan baris dibagi dengan elemen prioritas yang bersangkutan sehingga didapat lamda.

$$
\lambda=\frac{\sum \text { baris }}{\text { prioritas }} \quad \text { Persamaan } 1
$$

d. Jumlahkan lamda $(\lambda)$ dan hasilnya dibagi dengan banyaknya elemen yang ada, hasilnya disebut $\lambda$ maks.

$$
\begin{aligned}
& \lambda_{\text {maks }}=\frac{\sum \lambda}{n} \quad \text { Persamaan } 2 \\
& \text { dengan } \mathrm{n}^{2}= \\
& \text { dibandingkan. }
\end{aligned}
$$

E. Hitung Indeks Konsistensi/Consistency Index (CI) dengan rumus :

$$
\begin{aligned}
& C I=\frac{\left(\lambda_{\text {maks }}-n\right)}{n-1}=\text { banyaknya elemen yang } \\
& \begin{array}{l}
\text { dengan } \mathrm{n}= \\
\text { dibandingkan. }
\end{array}
\end{aligned}
$$

F. Hitung Rasio Konsistensi/Consistency Ratio (CR) dengan rumus :

$$
\begin{aligned}
& C R=\frac{C I}{R C} \quad \text { Persamaan } 4 \\
& \text { Dengan } \\
& \mathrm{CR}=\text { Consistency Ratio/konsistensi rasio } \\
& \mathrm{CI}=\text { Consistency Index/indeks konsistensi }
\end{aligned}
$$


$\mathrm{RC}=$ Random Consistency/konsistensi random

G. Memeriksa Konsistensi Hierarki

Setiap matriks perbandingan berpasangan perlu dilakukan uji konsistensi (CI), jika nilai CI $\leq 0,1$ maka pernyataan pada matriks dianggap konsisten, namun jika nilai CI > 0,1 maka pernyataan dianggap tidak konsisten artinya perlu dikaji kembali pemberian nilai tingkat kepentingan setiap kriteria, sub-kriteria dan alternatif. Nilai random Consistency Index (RI) dapat di lihat pada tabel 2.1 di bawah ini.

Tabel 2.1 Nilai Random Index (Saaty, 1990)

\begin{tabular}{|c|c|}
\hline Ukuran Matrik & Nilai RI \\
\hline 1,2 & 0,00 \\
\hline 3 & 0,58 \\
\hline 4 & 0,90 \\
\hline 5 & 1,12 \\
\hline 6 & 1,24 \\
\hline 7 & 1,32 \\
\hline 8 & 1,41 \\
\hline 9 & 1,45 \\
\hline 10 & 1,49 \\
\hline 11 & 1,51 \\
\hline 12 & 1,48 \\
\hline 13 & 1,56 \\
\hline 14 & 1,57 \\
\hline 15 & 1,59 \\
\hline
\end{tabular}

\section{METODE PENELITIAN}

\subsection{Blok Diagram Sistem}

Dalam Analisis Perbandingan Metode AHP dan TOPSIS Pada Sistem Pendukung Keputusan Pemilihan Menu Makanan Untuk Anak Pasca Operasi Hisphrung Berbasis Web untuk admin di tunjukkan pada Gambar 1 di bawah ini.

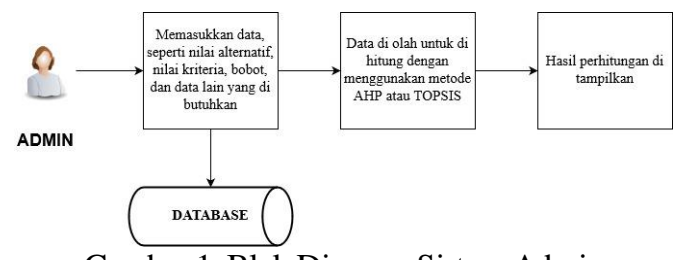

Gambar 1. Blok Diagram Sistem Admin

Pada blok diagram sistem di atas dapat di ketahui langkah awal admin akan memasukkan data, seperti nilai alternatif, nilai kriteria, bobot, dan data lain yang di butuhkan yang kemudian di simpan di database. Selanjutnya data akan di olah untuk di hitung dengan metode AHP dan TOPSIS. Setelah di hitung hasil perhitungan akan di tampilkan.

\subsection{Flowchart Sistem}

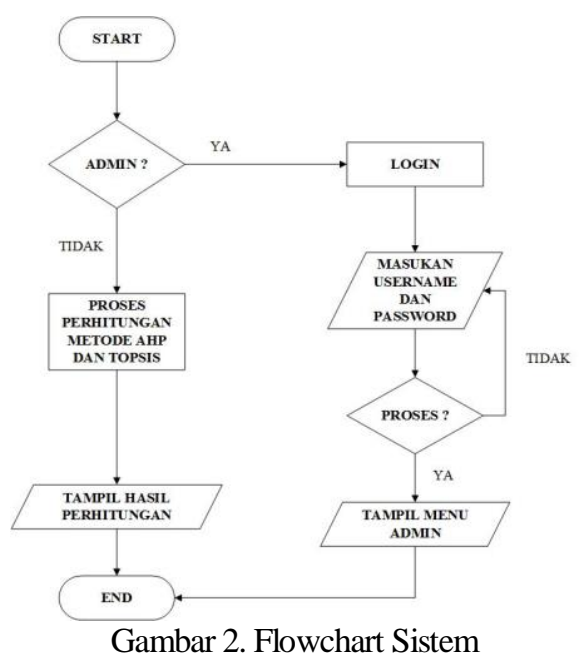

Pada Gambar 2 menjelaskan tentang proses alur dari sistem. Untuk bagian user tidak perlu melakukan login terlebih dahulu, jadi langsung melakukan perhitungan dengan menggunakan metode AHP dan TOPSIS. Untuk bagian admin harus melakukan proses login dengan memasukkan username dan pasword. Setelah melakukan login admin dapat melakukan memasukkan, mengedit, menghapus data kriteria dan alternatif. Melakukan perbandingan kriteria dan alternatif, input nilai.

\subsection{Flowchart Metode AHP}

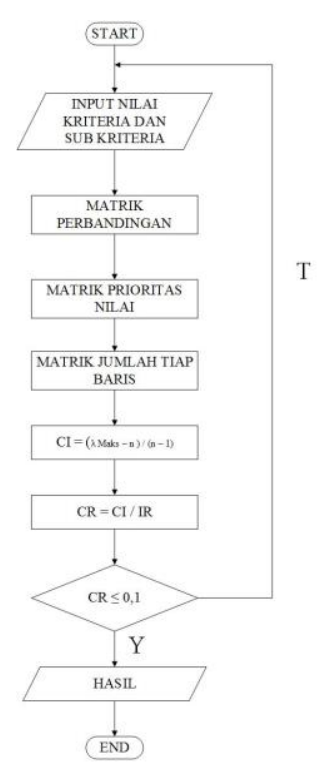

Gambar 3. Flowchart Metode ahp

Pada Gambar 3 langkah pertama dimulai dari memasukkan kriteria, alternatif dan sub kriteria. Kemudian di masukkan ke dalam matrik perbandingan. Selanjutnya di buatnya matrik prioritas nilai, setelah itu di lakukannya matrik jumlah tiap baris. Kemudian di lakukannya perhitungan $\mathrm{CI}$ dan $\mathrm{CR}$. 


\subsection{Flowchart Metode TOPSIS}

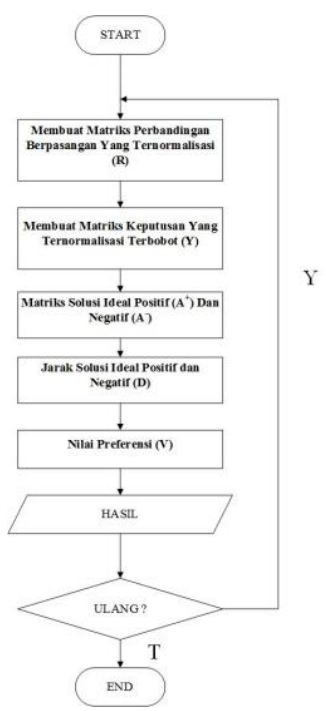

Gambar 4. Flowchart Metode TOPSIS

Pada Gambar 4 Langkah pertama yang harus di lakukan yaitu membuat matrik perbandingan berpasangan yang ternormalisasi. Kemudian membuat matrik keputusan yang ternormalisasi terbobot, setelah itu menghitung solusi ideal positif dan solusi ideal negatif. Selanjutnya menghitung nilai jarak solusi ideal positif dan jarak solusi ideal negatif. Kemudian menghitung nilai preferensi untuk mengetahui menu makanan yang terpilih.

\section{HASIL DAN PEMBAHASAN}

Dari perancangan yang di rencanakan sebelumnya, di dapatkan hasil yang akan di jelaskan di bawah ini.

\subsection{Implementasi Antarmuka Sistem}

a. Tampilan Halaman Beranda User

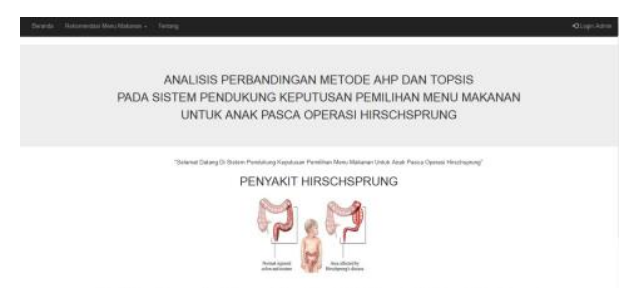

Gambar 4.1 Tampilan Halaman Beranda User

Pada Gambar 4.1 merupakan tampilan menu beranda. Halaman ini berisi tentang pengertian penyakit Hirschsprung dan di sertai dengan gambar. b. Tampilan Menu Rekomendasi Menu Makanan Metode TOPSIS

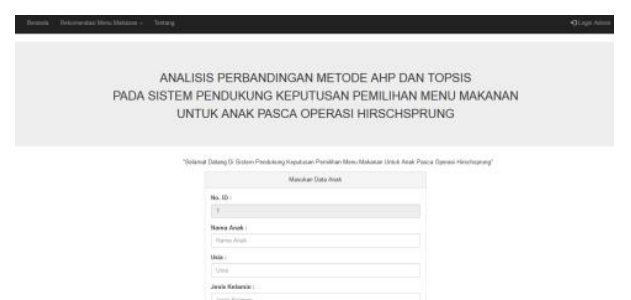

Gambar 4.2 Tampilan Menu Rekomendasi Menu Makanan Metode TOPSIS

Pada gambar 4.2 merupakan tampilan menu rekomendasi menu makanan metode TOPSIS. Pada halaman ini berisi tentang inputan berupa nama anak, usia, jenis kelamin, berat badan yang kemudian di proses dengan metode TOPSIS untuk mendapatkan rekomendasi menu makanan.

c. Tampilan Menu Rekomendasi Menu Makanan Metode AHP

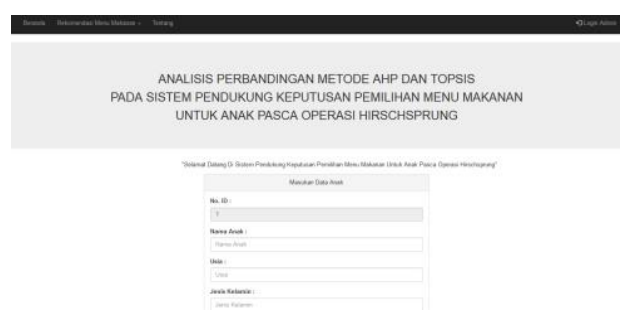

Gambar 4.3 Tampilan Menu Rekomendasi Menu Makanan Metode AHP

Pada gambar 4.3 merupakan tampilan menu rekomendasi menu makanan metode AHP. Pada halaman ini berisi tentang inputan berupa nama anak, usia, jenis kelamin, berat badan yang kemudian di proses dengan metode AHP untuk mendapatkan rekomendasi menu makanan.

\section{d. Tampilan Menu Tentang}

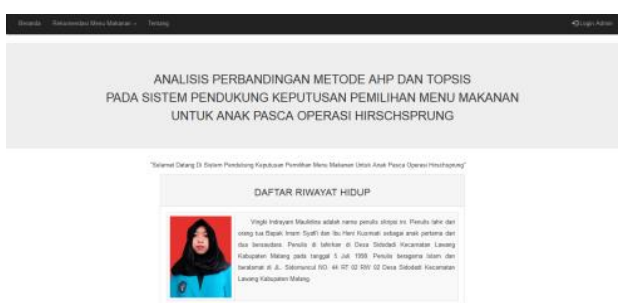

Gambar 4.4 Tampilan Menu Tentang

Pada Gambar 4.4 merupakan tampilan menu tentang. Halaman ini berisi tentang data diri dari pembuat aplikasi Analisis Perbandingan Metode AHP dan TOPSIS Pada Sistem Pendukung Keputusan Pemilihan Menu Makanan Untuk Anak Pasca Operasi Hisphrung Berbasis Web. 


\section{e. Tampilan Menu Login}

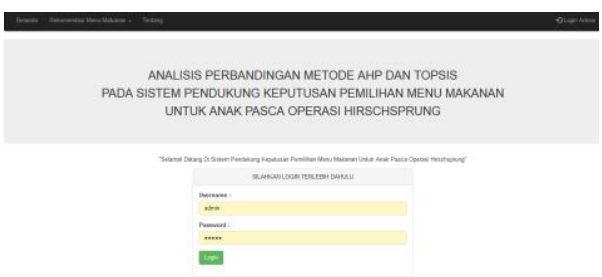

Gambar 4.5 Tampilan Menu Login

Pada Gambar 4.5 merupakan tampilan menu login. Halaman ini digunakan untuk memasukkan username dan password untuk masuk sebagai admin.

\section{f. Tampilan Menu Data Kriteria}

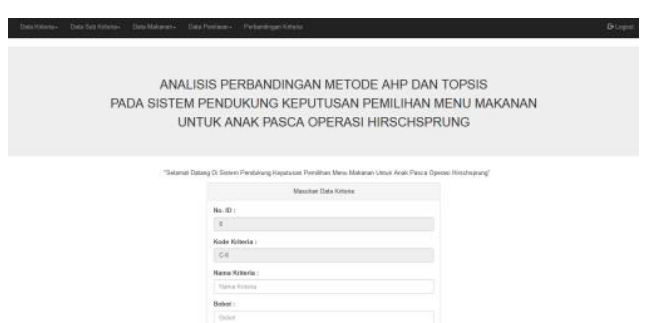

Gambar 4.6 Tampilan Menu Data Kriteria

Pada Gambar 4.6 merupakan tampilan menu masukkan data kriteria. Halaman ini digunakan untuk memasukkan data kriteria seperti No. ID, Kode Kriteria, Nama Kriteria, Bobot kemudian di simpan pada database yang di sajikan dalam bentuk tabel.

\section{g. Tampilan Menu Data Penilaian Metode AHP}

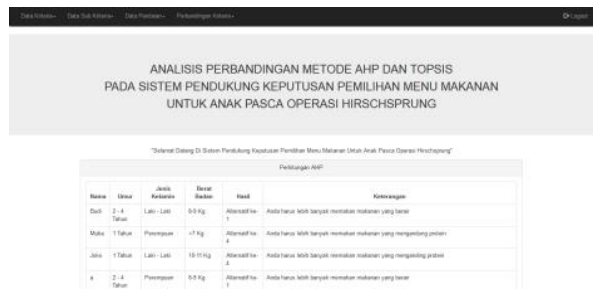

Gambar 4.7 Tampilan Menu Data Penilaian Metode AHP

Pada Gambar 4.7 merupakan tampilan menu Menu Data Penilaian Metode AHP. Halaman ini berisi tentang hasil penilaian yang telah di inputkan oleh user.

\section{h. Tampilan Menu Data Penilaian Metode TOPSIS}

Pada Gambar 4.8 merupakan tampilan menu Menu Data Penilaian Metode TOPSIS. Halaman ini berisi tentang hasil penilaian yang telah di inputkan oleh user.

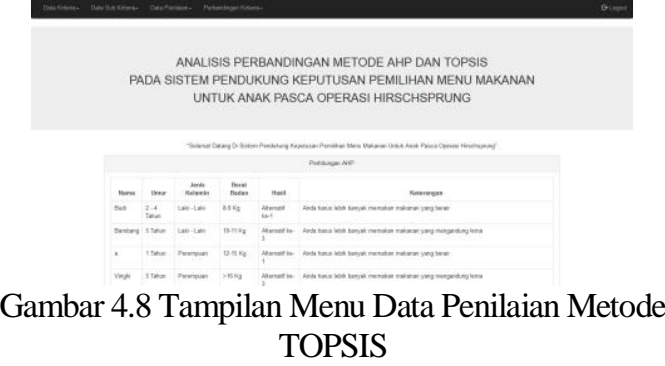

\subsection{Pengujian Kecepatan Waktu}

Pengujian kecepatan waktu dilakukan dengan membandingkan berapa lama pemrosesan data yang di lakukan. Hasil pengujian kecepatan waktu di tampilkan seperti di bawah ini :

Tabel 4.1 Pengujian Kecepatan Waktu

\begin{tabular}{|c|c|}
\hline Metode & Metode TOPSIS \\
\hline $\begin{array}{lrr}\text { Pada metode } & \text { AHP } \\
\text { program memerlukan } \\
\text { waktu sekitar } & \text { sekitar } \\
1.57 \text { detik } & \text { untuk } \\
\text { melakukan } & \text { proses } \\
\text { perhitungan. } & \end{array}$ & $\begin{array}{lr}\text { Pada metode } & \text { TOPSIS } \\
\text { program memerlukan } \\
\text { waktu sekitar } & \text { sekitar } \\
1.25 \text { detik } & \text { untuk } \\
\text { melakukan } & \text { proses } \\
\text { perhitungan. } & \end{array}$ \\
\hline
\end{tabular}

\subsection{Pengujian Fungsionalitas Menu}

Pada pengujian fungsionalitas sistem, dilakukan percobaan untuk menjalankan semua fungsi yang ada di sistem, apakah bekerja dengan normal atau tidak. Pengujian dilaukan pada 2 browser pada perangkat dengan spesifikasi CPU yang digunakan adalah intel Celeron CPU @ 1.90 GHz, RAM 2 GB, dan penyimpanan Harddisk.

Tabel 4.2 Pengujian Fungsionalitas Menu

\begin{tabular}{|l|c|c|}
\hline \multicolumn{1}{|c|}{ Menu Yang Diuji } & Sukses & Gagal \\
\hline Tampilan Home User & $\checkmark$ & \\
\hline $\begin{array}{l}\text { Tampilan Rekomendasi } \\
\text { Menu Makanan Metode } \\
\text { Topsis }\end{array}$ & $\checkmark$ & \\
\hline $\begin{array}{l}\text { Tampilan Rekomendasi } \\
\text { Menu Makanan Metode } \\
\text { AHP Dintang }\end{array}$ & $\checkmark$ & \\
\hline Tampilan Tentang & $\checkmark$ & \\
\hline Tampilan Login & $\checkmark$ & \\
\hline Tampilan Home Admin & $\checkmark$ & \\
\hline $\begin{array}{l}\text { Tampilan Masukkan Data } \\
\text { Kriteria }\end{array}$ & $\checkmark$ & \\
\hline $\begin{array}{l}\text { Tampilan Lihat Data } \\
\text { Kriteria }\end{array}$ & $\checkmark$ & \\
\hline $\begin{array}{l}\text { Tampilan Data Penilaian } \\
\text { Metode AHP }\end{array}$ & $\checkmark$ & \\
\hline $\begin{array}{l}\text { Tampilan Data Penilaian } \\
\text { Metode TOPSIS }\end{array}$ & $\checkmark$ & \\
\hline
\end{tabular}

\subsection{Pengujian User}

Pengujian user merupakan nilai atau respon yang diberikan oleh pengguna terhadap aplikasi. Pada pengujian ini di pilih user sebanyak 10 orang secara acak. Hasil dari pengujian user di tunjukkan pada tabel 4.3. 
Tabel 4.3 Pengujian User

\begin{tabular}{|c|c|c|c|c|}
\hline \multirow[b]{2}{*}{ No } & \multirow[b]{2}{*}{ Pertanyaan } & \multicolumn{3}{|c|}{ Hasil } \\
\hline & & 㫕 & $\underset{z}{\frac{z}{3}}$ & $\underset{\Xi}{ٍ]}$ \\
\hline 1 & $\begin{array}{l}\text { Apakah ukuran dan warna font } \\
\text { sudah terlihat dengan jelas? }\end{array}$ & 8 & 2 & 0 \\
\hline 2 & $\begin{array}{l}\text { Apakah tampilan website sudah } \\
\text { sesuai kebutuhan? }\end{array}$ & 6 & 4 & 0 \\
\hline 3 & $\begin{array}{l}\text { Apakah warna tombol dan } \\
\text { background pada aplikasi sudah } \\
\text { sesuai dan terlihat jelas? }\end{array}$ & 8 & 2 & 0 \\
\hline 4 & $\begin{array}{l}\text { Apakah tampilan menu-menu } \\
\text { program mudah dipahami ? }\end{array}$ & 7 & 3 & 0 \\
\hline 5 & $\begin{array}{l}\text { Apakah form-form yang ada pada } \\
\text { program sudah sesuai? }\end{array}$ & 7 & 3 & 0 \\
\hline 6 & $\begin{array}{l}\text { Apakah program membantu } \\
\text { mempermudah proses penentuan } \\
\text { siswa kurang berprestasi? }\end{array}$ & 6 & 4 & 0 \\
\hline \multicolumn{2}{|c|}{ Jumlah } & 42 & 18 & 0 \\
\hline
\end{tabular}

Berdasarkan hasil pengujian pada tabel di atas, dapat dijelaskan bahwa pengujian pada user dari 10 user dalam perhitungan :

Pertanyaan $1: 8$ baik, 2 cukup

Pertanyaan $2: 6$ baik, 4 cukup

Pertanyaan $3: 8$ baik, 2 cukup

Pertanyaan $4: 7$ baik, 3 cukup

Pertanyaan $5: 7$ baik, 3 cukup

Pertanyaan $6: 6$ baik, 4 cukup

Sehingga di dapat jumlah nilai baik sebanyak 42, nilai cukup sebanyak 18 dan nilai kurang sebanyak 0 .

Berdasarkan hasil kuesioner yang sudah dilakukan terhadap 10 user di atas, didapat hasil presentase untuk setiap jawaban dengan menggunakan rumus :

Keterangan :

$$
\frac{j}{a \times b} \times 100 \%
$$

$\mathrm{j}=$ jumlah yang menjawab baik,

cukup dan kurang

$\mathrm{a}=$ jumlah responden

$\mathrm{b}=$ jumlah pertanyaan

Responden menjawab Baik :

$$
\frac{42}{10 \approx 6} \times 100 \%=70 \%
$$

Responden menjawab Cukup :

$$
\frac{18}{10 \approx 6} \times 100 \%=30 \%
$$

Responden menjawab Kurang :

$$
\frac{0}{10 x^{6}} x 100 \%=0 \%
$$

Dari 3 range jawaban yaitu baik, cukup dan kurang, maka didapat hasil presentase $70 \%$ menjawab baik, 30\% menjawab cukup dan $0 \%$ menjawab kurang. Sehingga aplikasi ini dapat dikatakan baik serta dapat membantu orang tua dalam menentukan menu makanan yang cocok untuk di konsumsi.

\section{KESIMPULAN DAN SARAN}

\subsection{Kesimpulan}

Adapun kesimpulan yang dapat penulis uraikan setelah melakukan perancangan dan pembuatan Sistem Pendukung Keputusan Pemilihan Menu Makanan Untuk Anak Pasca Operasi Hisphrung Berbasis Web dengan menggunakan Metode AHP Dan TOPSIS adalah sebagai berikut :

1. Sistem Pendukung Keputusan Pemilihan Menu Makanan Untuk Anak Pasca Operasi Hisphrung Berbasis Web dengan menggunakan Metode AHP Dan TOPSIS dapat menentukan rekomendasi menu makanan.

2. Berdasarkan hasil pengujian kuisioner didapat hasil presentase $70 \%$ yang menyatakan baik, sehingga dapat di simpulkan bahwa metode AHP dan TOPSIS dapat di terapkan untuk menentukan rekomendasi menu makanan.

\subsection{Saran}

Berdasarkan kesimpulan yang telah diuraikan diatas, maka diberikan saran sebagai berikut :

1. Orang tua anak penderita penyakit Hisphrung dapat memanfaat sistem ini untuk membantu dalam pengambilan keputusan untuk pemilihan menu makanan.

2. Dengan adanya sistem ini orang tua dapat mengetahui menu makanan yang cocok untuk anak pasca operasi Hisphrung dengan mudah.

\section{DAFTAR PUSTAKA}

[1] Kumaladewi, R. R., Kusumadewi, S. (2015). Sistem Pendukung Keputusan Pemilihan Menu Makanan Bagi Anak. Seminar Nasional Informatika Medis (SNIMed) VI, p. 67.

[2] Marsono, W. D., Boy, A. F., \& Dari, W. (2015). Sistem Pendukung Keputusan Pemilihan Menu Makanan pada Penderita Obesitas dengan menggunakan Metode TOPSIS. Jurnal SAINTIKOM, 14.

[3] Siregar, Yustria Handika, and Sri Rahayu. "Sistem Pendukung Keputusan Pemilihan Menu Makanan Bagi Anak dengan Metode Analitycal Hierarchy Process (AHP)" Jurnal Teknologi Informasi, 2018.

[4] Latifah, E. L. (2012). Sistem Pendukung Keputusan Untuk Menentukan Menu Makanan Sehat Dengan Metode Elimination Et Choix Traduisant La Realité (ELECTRE). Universitas Islam Negeri Sunan Kalijaga : Yogyakarta.

[5] Aris Rakhmadi, S. T., \& Eng, M. (2016). Sistem Pendukung Keputusan Pemilihan Bahan Makanan Bergizi Untuk Manula Menggunakan Metode Simple Additive Weighting (Studi Kasus di Panti Jompo Laweyan) (Doctoral dissertation, Universitas Muhammadiyah Surakarta).

[6] Amiel J., Emison E., Barcello G., Lantieri F., Bursynsky G., Bornego S., et 
al.(2008).Hirschsprung disease, associated syndromes and genetics: a Review for theHirschsprung Disease Consortium.J. Med. Genet. 2008;45;1-14.

[7] Fatkhurrochman, \& Astuti, D. 2018. Analisis Perbandingan Metode Topsis dan SAW dalam
Penentuan Penerima Bantuan Pembangunan Rumah Masyarakat Kurang Mampu, 67-72.

[8] Eko Darmanto, Noor Latifah, Nanik Susanti. 2014. "Penerapan Metode AHP (Analythic Hierarchy Process) untuk Menentukan Kualitas Gula Tumbu". Jurnal SIMETRIS. Vol. 5, No. 1, Hal. 75-82. ISSN: 2252-4983. 